\title{
Article
}

\section{Identifying Salient Aktionsart Properties in Anindilyakwa}

\author{
James Bednall 1,2,3
}

1 School of Literature, Languages and Linguistics, Australian National University, Canberra, ACT 0200, Australia; james.bednall@anu.edu.au

2 Laboratoire de Linguistique Formelle, Université de Paris, 75006 Paris, France

3 ARC Centre of Excellence for the Dynamics of Language, The Australian National University, Canberra, ACT 2601, Australia

check for updates

Citation: Bednall, James. 2021 Identifying Salient Aktionsart Properties in Anindilyakwa. Languages 6: 164. https://doi.org/ 10.3390/languages6040164

Academic Editors: Elisabeth Mayer, Carmel O'Shannessy and Jane Simpson

Received: 31 January 2021

Accepted: 25 September 2021

Published: 9 October 2021

Publisher's Note: MDPI stays neutral with regard to jurisdictional claims in published maps and institutional affiliations.

Copyright: (C) 2021 by the author. Licensee MDPI, Basel, Switzerland. This article is an open access article distributed under the terms and conditions of the Creative Commons Attribution (CC BY) license (https:// creativecommons.org/licenses/by/ $4.0 /)$.

\begin{abstract}
This article considers the identification and classification of salient Aktionsart properties in Anindilyakwa (Gunwinyguan, Australia). Through examining the grammatically permissible (and impermissible) distribution and co-occurrence of various temporal adverbials and morphosyntactic structures, I identify key Aktionsart properties exhibited in Anindilyakwa. I demonstrate that the properties of dynamism and atomicity are particularly important to consider in this language, while telicity is less prominent. The detailed description and analysis of Aktionsart properties in this article contributes towards a more nuanced understanding of the aspectuo-temporal system of Anindilyakwa. In addition, it provides novel perspectives with which to consider cross-linguistic aspectuo-temporal research, particularly with a focus on smaller-scale, under-described languages.
\end{abstract}

Keywords: Aktionsart; aspect; semantics; Anindilyakwa; Australian Indigenous languages

\section{Introduction}

This article provides an in-depth examination of Aktionsart properties in Anindilyakwa (Gunwinyguan), the language of the Groote Eylandt archipelago, in the Gulf of Carpentaria, Australia.

Research into Aktionsart ${ }^{1}$ has a long and rich history in the philosophic and linguistic literature, however the vast majority of this research has been heavily biased towards a handful of widely-spoken, global languages. Over the last few decades efforts to investigate this topic cross-linguistically have increased (cf. Smith 1996; Tatevosov 2002), however there remains almost no comprehensive research in this domain considering Australian Indigenous languages. ${ }^{2}$ This article seeks to bridge this gap, providing a detailed account of Aktionsart in an Australian language.

The intersection between lexical properties of the verbal complex (i.e., Aktionsart) and the system of inflectional marking of the verb is integral to TAM expression in Anindilyakwa. Anindilyakwa demonstrates a high degree of aspectuo-temporal underspecification in its inflectional system, and therefore Aktionsart properties (as well as discourse and contextual factors) are particularly salient in distinguishing between different aspectuo-temporal readings. A detailed understanding of Aktionsart is therefore essential.

The article is organised as follows. Section 2 provides a typological background of Anindilyakwa, in addition to an overview of the data and methods used in this study. In Section 3, I provide an overview and a brief history of research within the domain of Aktionsart, highlighting in particular the influential work of Vendler (1957) in Section 3.1, along with the key Aktionsart parameters that I consider in this study in Sections 3.2 and 3.3. I consider cross-linguistic perspectives relating to Aktionsart in Section 3.4 before focusing on language-specific Aktionsart features and how they are established in Anindilyakwa in Section 4. Section 5 provides concluding remarks and avenues for future research. 


\section{Anindilyakwa}

Anindilyakwa is a Gunwinyguan language spoken on the Groote Eylandt archipelago, east Arnhem Land, Northern Territory (see Figure 1). It is a vibrant language, spoken by over 1400 people and is one of the few Australian languages still being acquired by children. ${ }^{3}$

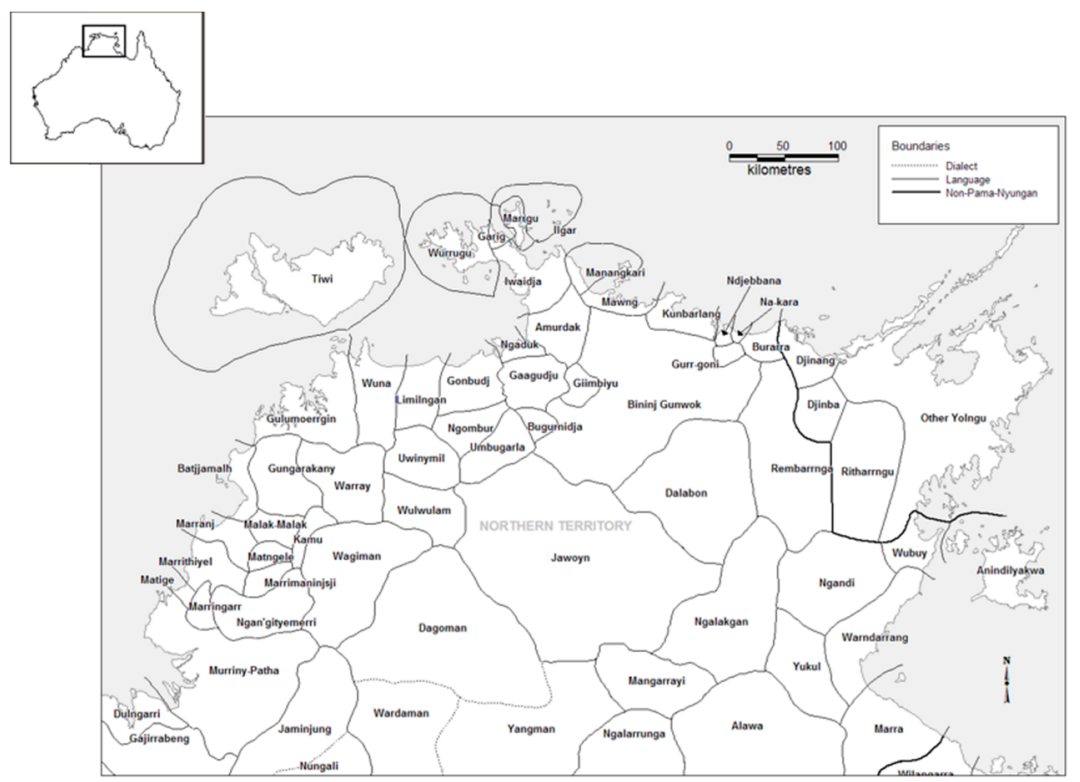

Figure 1. Languages of norther Australia (Harvey 2008).

\subsection{Typological Overview}

Typologically, Anindilyakwa has been noted for its polysynthetic structure and morphological complexity. It is a head-marking language, marking core arguments on the verb. It has a productive system of nominal incorporation, and employs various argumentchanging affixes within the verbal template (Bednall 2020, p. 7). The verbal complex is the most elaborate word class in the language, comprising verb stems that historically consist of an uninflecting verb root plus an inflecting element, and involve multiple (2+) discontinuous morphs to express different temporal, aspectual and modal categories. Compare, for instance, example (1) expressing a past temporal reading with REALIS-V-PAST verbal marking, to example (2) expressing a future temporal reading with IRREALIS-V-NPST marking.

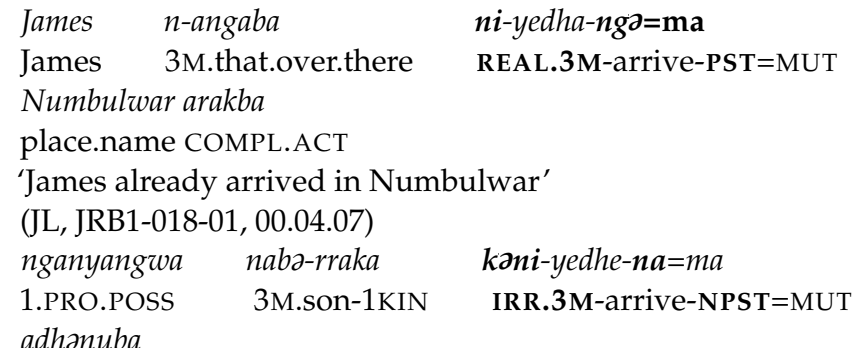

adhanuba

in.short.time

'My son will arrive soon'

(JL, JRB1-044-01, 00:11:37-00:11:44)

\subsection{Data for This Study}

Data for this study are drawn primarily from a corpus collected by the author in 2016-2019. ${ }^{4}$ Data were documented through a variety of methods in order to produce results that are as robust as possible, including (i) semi-structured elicitation using visual video stimuli, ${ }^{5}$ (ii) tense-aspect questionnaires, and (iii) grammaticality judgment tasks. These all targeted different kinds of aspectuo-temporal categories, Aktionsart parameters 
and complex event structures. These elicited and semi-elicited tasks were complemented by a collection of audio-recorded and text-based narratives.

Aktionsart tests involved asking Anindilyakwa language consultants for judgements of acceptability, truth, and felicity of sentences in Anindilyakwa. Data involving less complex situations were first examined (considering, for instance, situations involving no change (e.g., n-akana nenangkwarba n-ambilya yelakwa (3M-that 3M.man REAL.3M-stay.PST here) 'the man stayed here'; stative, durative, non-atomic) or a clear change of state (e.g., $n$ akana nenangkwarba ni-junga-na (3M-that 3M.man REAL.3M-die-PST) 'the man died'; dynamic, instantaneous, atomic), before then turning to more complex event structures.

In addition to data collected via careful elicitation, natural narrative corpus data were examined to confirm hypotheses based on Aktionsart tests. For example, the distribution and collocations of adverbials that were examined in the Aktionsart tests were investigated in the corpus data, in order to confirm the results that emerged from the elicited tests and activities. The combination of careful elicitation, speakers' grammaticality judgements and naturalistic data (comprised of oral narratives and texts) means that we can be more confident of the properties discussed and the claims made in this article. Of course, the variables examined are not necessarily exhaustive, and further research in this area could further uncover other variables of relevance.

\section{Aktionsart}

Aktionsart refers to the intrinsic aspectual properties of the verbal complex, determined by the disambiguated, contextualised semantics of the verbal complex (Caudal 2012, p. 272). I assume a two-component theory of aspect (à la Smith 1997), where Aktionsart is distinguished from viewpoint aspect. Viewpoint aspect, in contrast, refers to the grammatical marking of the speaker's perspective of the event, denoting how much of the event is made visible (e.g., the whole event, or only a subpart of an event), and is generally expressed through inflectional tense-aspect marking.

In examining Aktionsart, it is the aspectual properties of the verbal complex (i.e., the verb and its arguments; the verb as interpreted in combination with complements, adjuncts and modifiers) that we are concerned with. While it has sometimes been assumed that the domain under examination is the verb (thus Aktionsart being a classification of verbs themselves), Verkuyl (1972) and Dowty $(1972,1979)$ (and much subsequent literature) have made clear that Aktionsart should be understood not as a lexical parameter, but a structural one, involving sentence meaning: the verbal complex/constellation (comprising of the verb, its arguments, adjuncts and modifiers) all of which play a role in determining Aktionsart properties (Moens 1987, pp. 59-60).

While these intrinsic properties are fundamental to aspectual expression across the world's languages, the salience of Aktionsart properties and how they interact with other aspectuo-temporal elements (in particular, with viewpoint aspect, tense and (aspectuotemporal) adverbials) differ substantially cross-linguistically (cf. Tatevosov 2002).

\subsection{Vendler Classes}

The place of Aktionsart in the modern semantics literature is couched in research on Indo-European languages (particularly English), and draws principally on the work of philosopher Zeno Vendler. Vendler's (1957) seminal article proposed that clusters of syntactic properties can be used to characterise different situation types (i.e., general semantic categories that represent classes of idealised situations, that are organised according to their semantic temporal properties) (Smith 1996, p. 228). Vendler proposed four such Aktionsart 'classes', used to classify situations: States, Activities, Achievements and Accomplishments. These four classes, along with a subsequent fifth class, Semelfactives (cf. Comrie 1976), have consequently proven very influential in Aktionsart research. Table 1 lists these five classes, along with the intrinsic temporal properties by which they are frequently differentiated.

As shown in Table 1, the temporal properties of dynamism (i.e., whether a situation is perceived as being static or dynamic), telicity (i.e., whether or not there is an inherent end- 
point to a situation), and durativity (i.e., the duration of a situation) have traditionally been acknowledged as central domains involved in Aktionsart (discussed further in Section 3.2). In more recent work, however, further proposals for distinguishing Aktionsart parameters have been made, taking into account situations that don't neatly fit the Vendler system. In particular, these include events involving scalarity (including e.g., gradual changes of state (i.e., degree achievements à la Dowty 1979)) (cf. Caudal 2005; Kennedy and McNally 1999, 2005). This is considered in relation to Anindilyakwa in Section 4.

Table 1. Properties distinguishing Aktionsart classes (Smith 1997, p. 20).

\begin{tabular}{llll}
\hline & Dynamic & Telic & Durative \\
\hline State & - & - & + \\
Activity & + & - & + \\
Accomplishment & + & + & + \\
Achievement & + & + & - \\
Semelfactive & + & - & - \\
\hline
\end{tabular}

While Vendler's Aktionsart classes have been very influential in research on Aktionsart, the diagnostics used to isolate and differentiate these temporal distinctions are heavily based on English data. It is clearly problematic to make cross-linguistic assumptions based on just a small subset of languages, thus it is imperative that Aktionsart parameters are established separately for individual languages, using language-specific means (Smith 1996, p. 228). This is explored further in Sections 3.4 and 4.

\subsection{Aktionsart Properties}

As demonstrated in Table 1, dynamism, telicity, and durativity have traditionally been considered central temporal properties associated with Aktionsart. I acknowledge these three properties. However, the core temporal properties I assume are dynamism and telicity, along with atomicity (i.e., whether an event can be split up into intermediary subparts, or involves only a one-step change of state). The property of durativity is also discussed in relation to telicity and atomicity. I outline these properties in Sections 3.2.1-3.2.4.

In this section I also briefly consider how these properties are related to stage structure (i.e., how situations are decomposed into distinct stages).

\subsubsection{Dynamism}

Dynamism is the quality determining whether a situation is static or dynamic. Statives consist of a single, undifferentiated period (i.e., which entails no change). Statives differ from atelic dynamic events (i.e., activities), in that dynamic events like activities involve some agent or controller of the event (including implicit controllers, such as natural force), while statives do not. Unless there is some disturbance, statives have the capacity to continue indefinitely, without effort (Comrie 1976). Examples of statives in English are 'the teacher is at school' and 'the student knows the answer', while examples of dynamic events in English are 'the athlete runs', 'the choir sings' and 'the train leaves the station'.

Stative situations can be further classified into stage-level and individual-level statives. Stage-level statives are associated with expressing temporary or accidental properties (such as 'the child is thirsty' or 'the customer is angry'), while individual-level statives are associated with permanent or inherent properties (such as 'John is short' or 'Mary is a doctor') (Carlson 1977, 1980).

\subsubsection{Telicity}

Telicity is concerned with the presence or absence of some endpoint or limit. Telic situations possess a 'natural finishing point beyond which the same event cannot continue, because it is finished' (Kearns 2000, p. 202). Thus, telic situations include sentences that encompass the final endpoint in their inherent meaning, such as English sentences involving 'to finish', 'to arrive' and 'to fill up'. Example (3) provides an example of a telic 
(dynamic, non-atomic, durative) situation in English.

3. 'Mary walked to school in an hour'

(Smith 1997, p. 43)

In contrast, atelic situations do not have an intrinsic endpoint or termination point specified. Their endpoints are arbitrary, with the situation able to continue indefinitely (Kearns 2000, p. 202) (such as stative situations like 'John believes Mary' and 'Joan knows Spanish', and dynamic events like 'Jill swims' or 'Patrick sits on the beach'). Example (4) provides an example of an atelic (dynamic, non-atomic, durative) situation in English.

4. 'Mary walked in the park for an hour'

(Smith 1997, p. 43)

\subsubsection{Atomicity}

Atomic events involve a holistic, one-step change-of-state which cannot be interrupted and then resumed. They are devoid of proper subparts (i.e., they are comprised of only two points in time (a minimal and a maximal one) needed for the change of state to occur), e.g., 'the man died', 'the bomb exploded'. Non-atomic situations, on the other hand, involve a complex change-of-state, and its development can be measured along intermediary subparts (which follow a complex development scale) (Caudal 2005, p. 104). (Non-)atomicity interacts closely with the notion of incrementality (i.e., a property of verbs whose development can be mapped onto the internal structure of one of their arguments, as in (Dowty 1991)) (Caudal 1999, p. 3). Tests for atomicity in English include the ability to occur with 'finish', the perfect progressive, and degree adverbials (such as 'completely'), as shown in examples (5) and (6) (Caudal 2005, p. 104).

5. a. 'The boy finished eating his porridge' (non-atomic)

b. 'The boy has been eating his porridge'

c. 'The boy ate his porridge completely'

(Caudal 2005, p. 104)

6. a. *'The boy finished leaving' 6

(atomic)

b. \#'The boy has been leaving' (ok with iterative reading)

c. \#'The boy left completely' (ok with frequentative)

While atomic events are generally non-durative, and non-atomic situations generally durative, this is not always necessarily the case: atomic events can be durative (as in example (7)), and non-atomic events can be instantaneous (as in example (8)). Atomicity should not be confused with punctuality, which is a combination of both atomicity plus non-durativity (Caudal 2005, p. 105).
7. 'The supernova exploded'
(atomic, durative)

a. ¿The supernova finished exploding'

b. “The supernova has been exploding'

c. *The supernova exploded completely'

8. 'John crushed the seed'

a. 'John finished crushing the seed'

b. 'John has been crushing the seed'

c. 'John crushed the seed completely'

\subsubsection{Durativity}

Durativity is a temporal concept, concerned with the temporal extent or duration of a situation. Durative situations occur (or have the potential to occur) with some temporal extent (such as 'she talks', 'he eats', 'the mechanic fixes the car' or 'the explorer climbs a mountain' in English), while non-durative situations are momentary transitions from one state of affairs to another (such as 'the visitors arrive', 'he finds the key' or 'the dog dies' in English). Durative events are generally non-atomic, although as mentioned above, this is not always the case. 


\subsection{Stage Structure}

In discussing Aktionsart properties, it is also helpful to consider stage structure. Stage structure is topological, involving situation 'chunks': preparatory, inner, and result stages (cf. Moens and Steedman 1988).

Following Caudal and Roussarie (2000) and Caudal $(2005,2006)$, I assume that aspectual properties of each (disambiguated, contextualised) verbal complex occur in a stage structure, in which situations are decomposed into distinct stages (or subevents):

(i) Preparatory stages: causal event stages involved in some types of atomic telic events. Preparatory stages are selected (e.g., in English) under prospective readings of the past progressive (e.g., 'Mona was reaching the summit'). These stages are peripheral to the stage structure (i.e., 'detachable' from the stage structure (cf. Smith 1997), having a presuppositional status (they remain valid under negation and modals-e.g., John did not win the race nevertheless entails that John took part in the race);

(ii) Inner stages: 'core' stages of all situations (what Smith (1997) calls 'developments'). If a situation is telic then the inner stages include its culmination. Inner stages of telic situations are selected (e.g., in English) by unmarked uses of the past progressive or simple past (e.g., 'Mona reached the summit'), and if non-atomic, by 'begin' and 'start';

(iii) Result stages: stative result stages, applicable to all situations (although with major differences apparent between telic and atelic situations). They can be selected (e.g., in English) by the perfect (e.g., 'Mona has reached the summit') (Caudal and Roussarie 2000, p. 362).

These three stages are demonstrated in Figure 2, for the atomic event 'Mona REACH the summit'.

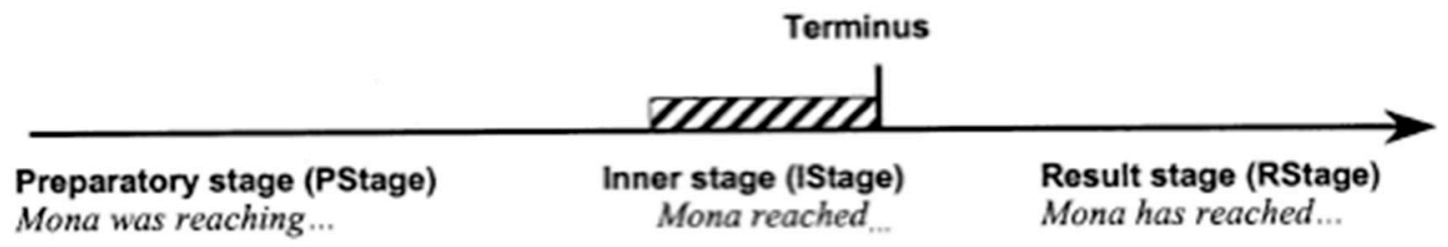

Figure 2. Stage structure for verbal complex 'Mona REACH the summit' (Caudal and Roussarie 2000, p. 362).

\subsection{Typological Perspective}

As has been established in Sections 3.1-3.3, Vendler's classes and the diagnostic tests used to establish Aktionsart properties of different situations are heavily biased to Indo-European (particularly English) data. As such, they are not necessarily transferable for use with other languages cross-linguistically. Despite this, a widespread (often tacit) assumption is that the parameters and notions on which Vendler's classes are established are universal (i.e., are not subject to cross-linguistic variation). A consequence of this, as pointed out by Tatevosov (2002, p. 322), has been that many linguists have worked under the assumption that situations in every language can be classified into Vendlerian classes as established for English (perhaps with minor modifications), as has been displayed by dozens of language-specific studies of aspect (e.g., cf. language-specific chapters in Bache et al. 1994).

While it is not a trivial task to identify language-specific Aktionsart parameters in a given language (Filip 2012, p. 724), clearly it is imperative for these parameters to be established separately for individual languages, using language-specific means (Smith 1996, p. 228), and that the cross-linguistic application of such diagnostic tests is not taken for granted (Filip 2012; Sasse 2002).

Despite the English and more broadly Indo-European bias in Aktionsart research, acknowledgement and examination of cross-linguistic variation with respect to Aktionsart has been the subject of various studies. Notable works include that of Smith (1997), which considers Aktionsart in Mandarin Chinese and Navajo (in addition to the more widely 
studied English, French and Russian), with Navajo examined in particular detail also in Smith (1996). Tatevosov (2002) provides probably the most extensive investigation to date examining cross-linguistic variation relating to Aktionsart and provides an in-depth discussion about methods for cross-linguistic approaches to examining Aktionsart.

\section{Aktionsart in Anindilyakwa}

Intrinsic temporal properties of the verbal complex are integral to the system of aspectual expression in Anindilyakwa. Examining and understanding Aktionsart in this language is particularly relevant given that its inflectional system demonstrates a high degree of aspectuo-temporal underspecification.

In Anindilyakwa TAM expression is realised inflectionally through combining (at least) two obligatory, discontinuous morphological slots of the verbal template. One of three series of portmanteau prefixes (REALIS; IRREALIS; DEONTIC) combines with one of four TAM suffixes (NON-PAST; PAST; UNDERSPECIFIED (Ø); POTENTIAL), resulting in different possible TAM readings, including the aspectually underspecified REALIS-V-PAST and aspectuo-temporally underspecified REALIS-V-USP. Table 2 shows the different possible inflectional combinations, and some of their core TAM readings (for further information see Bednall 2020, chp. 6 and 9).

Table 2. Combinations of prenominal prefix and TAM suffix paradigms (positive polarity). ${ }^{7}$

\begin{tabular}{lll}
\hline Portmanteau Prefix & TAM Suffix & Core TAM Readings \\
\hline \multirow{2}{*}{ REALIS- } & -NON-PAST & Indicative present \\
\cline { 2 - 3 } & -PAST & Indicative past (aspectually underspecified) \\
\cline { 2 - 3 } & -UNDERSPECIFIED $(\varnothing)$ & $\begin{array}{l}\text { Indicative past/present (temporally and aspectually } \\
\text { underspecified) }\end{array}$ \\
\hline & -POTENTIAL & $\begin{array}{l}\text { Future; deontic (incl. imperative, hortative); epistemic; } \\
\text { dynamic (capacity, ability) }\end{array}$ \\
\cline { 2 - 3 } IRREALIS- & -PAST & Foreclosed counterfactual (deontic, epistemic, bouletic) \\
\cline { 2 - 3 } & -UNDERSPECIFIED $(\varnothing)$ & $\begin{array}{l}\text { Future; deontic (incl. imperative, hortative); epistemic; } \\
\text { dynamic (capacity, ability) }\end{array}$ \\
\cline { 2 - 3 } & -POTENTIAL & $\begin{array}{l}\text { Future; deontic (incl. imperative, hortative); epistemic; } \\
\text { dynamic (capacity, ability) }\end{array}$ \\
\hline \multirow{2}{*}{ DEONTIC- } & Deontic (incl. imperative, hortative) \\
\hline & -NON-PAST & Deontic (incl. imperative, hortative) \\
\hline
\end{tabular}

Given the aspectuo-temporally underspecified nature of the inflectional system, Aktionsart properties (as well as discourse and contextual factors) often play an important role in distinguishing between different aspectuo-temporal readings. Thus, understanding Aktionsart properties and the intersection between lexical properties of the verbal complex and the system of inflectional verbal marking is key to understanding the overall aspectual system.

In this section I identify salient Aktionsart properties in Anindilyakwa by examining the grammatically permissible (and impermissible) distribution and co-occurrence of various temporal adverbials (primarily measure adverbials and indirect duration adverbials), as well as through examining morpho-syntactic properties of reduplication patterns and inflectional TAM marking. Through the examination of these Aktionsart properties and the variables with which they can be identified, I demonstrate that the properties of dynamism and atomicity are particularly salient in Anindilyakwa, while telicity is less prominent. 
15.

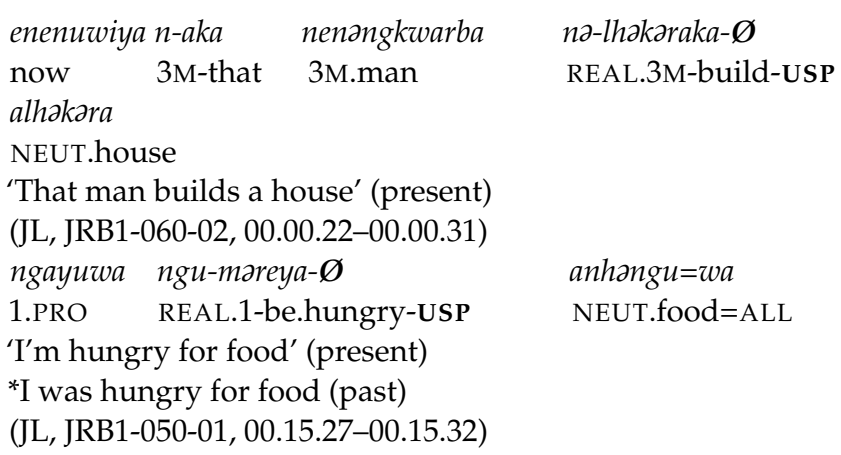

A summary of the effects of Aktionsart on the aspectuo-temporal properties of verbs inflected with REALIS-V-USP marking (particularly highlighting the unavailability of past temporal reference for statives) is shown in Table 3.

Table 3. Aktionsart and temporal effects.

\begin{tabular}{lccc}
\hline & Statives & $\begin{array}{c}\text { Dynamic } \\
\text { Non-Atomic Events }\end{array}$ & Atomic Events \\
\hline Past Perfective & $x$ & $\checkmark$ & $\checkmark$ \\
Ongoing Present & $\checkmark$ & $\checkmark$ & $\times$ \\
\hline
\end{tabular}

\subsection{Telicity}

Telicity refers to the presence or absence of some endpoint or limit. While there are grammatical correlates for telicity in Anindilyakwa, they are not as salient as other temporal parameters such as atomicity, for instance (which appears to play a much more important role in the acceptable distribution of various grammatical properties of the language; see Section 4.3).

There are distributional correlates for telicity distinctions in many languages, such as in English, where telic verbs are compatible with verbs and adverbials of completion (e.g., 'finish'; 'in an hour'), but are ill-formed with verbs and adverbials of simple duration (e.g., 'stop', 'for an hour'). In such languages, the inverse is true of atelic verbs (i.e., compatible with verbs and adverbials of simple duration (e.g., 'stop'; 'for an hour'), ill-formed with verbs and adverbials of completion (e.g., 'finish'; 'in an hour')) (Smith 1996, p. 236). Anindilyakwa shows some similar restrictions in its distribution of measure adverbials with different situation types, however while in English these restrictions are based on telicity distinctions, in Anindilyakwa they are dependent upon atomicity properties of the verbal complex (i.e., both telic and atelic events are grammatical and well-formed in combination with measure adverbials; see Section 4.3).

One area in which telicity does appear to play a role in determining acceptable distributional correlates in Anindilyakwa, however, involves reduplication. Verbal reduplication acts as an Aktionsart/stage-aspect modifier with atelic situations, centring on the 'core' inner stages in order to focus on the progression of the situation. Reduplicated verb roots of atelic situations can express these prolonged/extended/continuous aspectual readings, in addition to pluractional aspectual readings. With telic situations, however, only pluractional readings may be expressed. Compare, for instance, the atelic situation in (17) to the telic one in (18). Additionally, while reduplicated verb roots of telic situations in positive polarity contexts can be inflected with the bare stem paradigm (i.e., with a phonologically $\varnothing$ suffixal TAM slot), as in (18), this is not permissible with atelic ones, as in (19).

17.

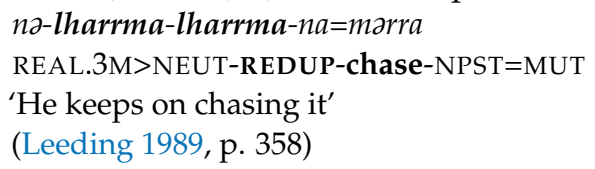


'It [the mother cat] kept going back [i.e., repeatedly going and returning], it ran off' (GL, A3369a Side 1 a3.4, Bujikeda 'Mother cat', 00.07.28-00.07.32)

Other tests for telicity involving scalarity (such as examining proportionate degree modifiers such as 'partially' /'completely') are not productive in Anindilyakwa, given that these adverbials (e.g., enangangkawura 'thoroughly, completely') are multifunctional, being able to express readings associated with both proportionate degree modification ('thoroughly' /'completely'), as well as habituality/durational extent ('always' /'forever').

\subsection{Atomicity}

The property of atomicity is a salient semantic feature in Anindilyakwa, key to distinguishing between different kinds of situations. Non-atomic events are those that involve a complex change-of-state whose development can be measured along its sub-parts, and which can be resumed if interrupted (Caudal 2005, p. 104) (e.g., nakana nenangkwarba namebina emeba 'the man sings', dhakana dhadharrangka yingilhakana mijiyelyuwa 'the woman goes to the beach'), while atomic events involve a holistic one-step change-of-state (i.e., only two points in time, a minimal and maximal one) (e.g., nijungəna 'he dies', yingilyumadhəna 'she disappears', narrongawardena 'she kills them', narrenangajina 'he kills them').

There are various grammatical distinctions in Anindilyakwa that correlate with properties of atomicity. Durational adverbials (measure adverbials and implied durational adverbials) are particularly useful diagnostics for these parameters in Anindilyakwa. The inflectional $\mathrm{T} / \mathrm{A}$ system (specifically the combination of the REALIS pronominal prefix paradigm with the bare stem paradigm (i.e., the phonologically $\varnothing$ suffixal TAM slot)), is also sensitive to properties of atomicity, observable through the available temporal interpretation of the verbal complex.

\subsubsection{Measure Adverbials}

In English, measure adverbials (e.g., 'for an hour') are compatible with atelic situations, but incompatible with telic ones. Telic situations are either ungrammatical with these adverbials, or they are coerced to behave differently, taking either an ingressive interpretation (relating to the interval before the event takes place), or triggering the interpretation of a durative event with internal stages (e.g., cough for an hour) (Smith 1996, p. 235).

In Anindilyakwa there are two measure adverbials, ${ }^{8}$ adhuwaya 'for short [duration of] time' and amiyerra 'for long [duration of] time', used to express the duration of time of a situation. Unlike the examples of English provided above, these are not used as diagnostics of telicity in Anindilyakwa, but rather of atomicity. Both telic and atelic events are grammatical and well-formed in combination with these adverbials. Atomic events, however, are disallowed in combination with these adhuwaya and amiyerra measure adverbials.

Examples (20) and (21) demonstrate the compatibility of adhuwaya and amiyerra with atelic, non-atomic, durative events (including statives (20) and dynamic, non-atomic events (21)), and examples (22)-(25) demonstrate their compatibility with non-atomic, durative, telic events. As demonstrated by examples (24) and (25), culmination does not affect the compatibility of adhuwaya and amiyerra (i.e., these measure adverbials are equally compatible with culminating and non-culminating readings). ${ }^{9}$ 
20.

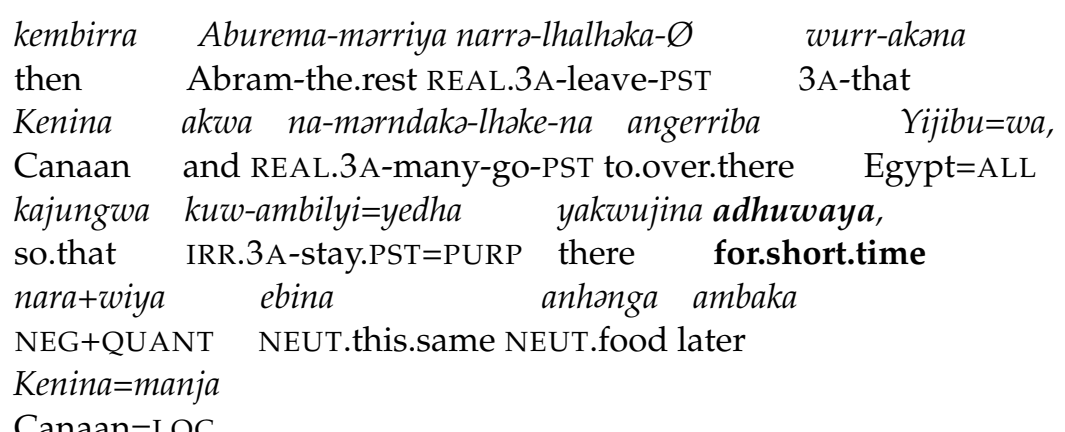

Canaan $=\mathrm{LOC}$

'There was so little food that Abram and his family left Canaan and went down to Egypt to live there for a while'

(Bible Society in Australia 1992, p. 83)

21. amiyerra ambak mema kamว-dhadho-na=ma

long.time later VEG.this IRR.VEG-become.cooked-NPST=MUT

'It'll take a while to cook these yams'

(JL, JRB1-049-01, 00:54:11.494-00:54:14.069)

22.

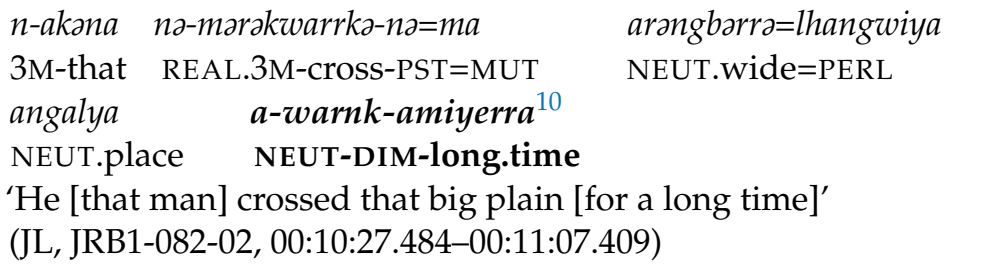

23.$$
\text { JL, JRB1-082-02, 00:10:27.484-00:11:07.409) }
$$
3M-that 3M.man
n-akana

nenjarrngalya adhuwaya

3M.boy for.short.time

'That man saved [the] little boy for a little while' [i.e., 'maybe when he was having this heart attack, or something like that, then he [the man] was trying his best [to save him] ... maybe he got better for a little while ... [but afterwards, maybe the boy got better, maybe he didn't], we don't know' (JL, JRB1-089-01, 00:24:49.735-00:25:09.915)

24.
n-akana nenangkwarba
nen-eniba-ka- $\varnothing=m a$
n-akana
3M-that 3M.man
REAL.3M>3M-alive-FACT-PST $=$ MUT 3M-that
nenjarrngalya
amiyerra
yandha+lhangwa
$n$-enib $=$ dha
3M.boy for.long.time nothing+ABL [until] 3M-alive=TRM

'That man brought the life of that boy, young man, for a while, until [he] was back to life'

(JL, JRB1-089-02, 00:19:04.875-00:20:40.145)

25

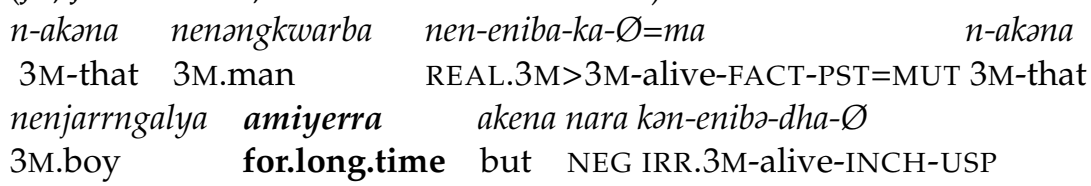

'That man, he brought the boy's life [back, for a] little while, but he never brought him back, just for a little while, then he was gone, he never came back to life'

(JL, JRB1-089-02, 00:20:53.200-00:23:27.270)

For telic situations, as in (22)-(25), the adverbial modifies the inner stages of the situation, leading up to (but not including) its culmination. Figure 3 demonstrates this modification of the inner stages of the event 'he crossed that big plain' (example (22)), by the measure adverbial amiyerra 'for short time'. 
$\mathrm{E}=$ cross (he, the big plain)

E, R

S

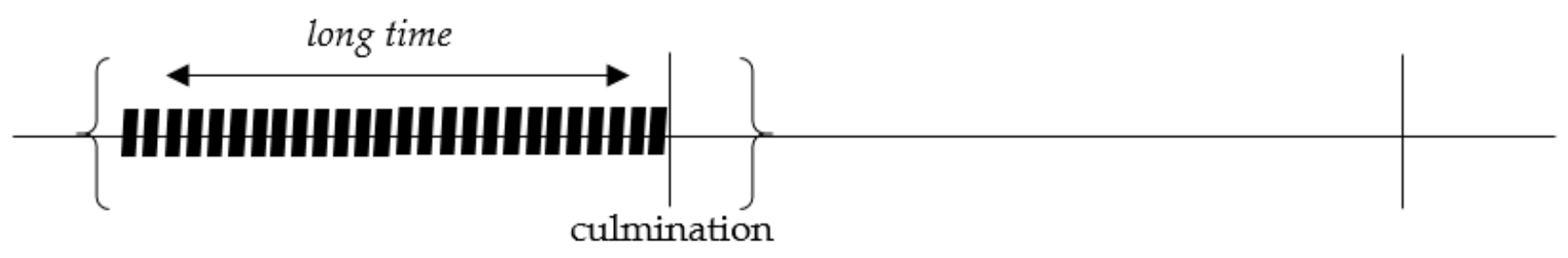

Figure 3. 'He crossed that big plain [for a long time]'.

Adhuwaya and amiyerra can only occur grammatically with atomic verbal complexes if they coerce an iterative reading, as in examples (26) and (27).

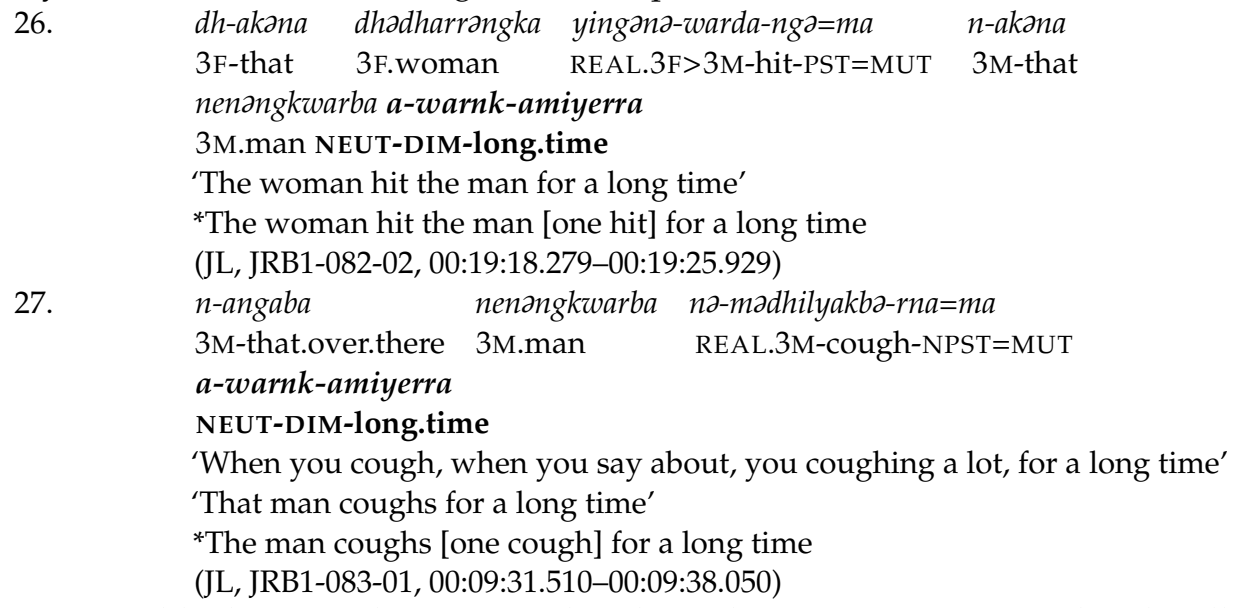

Anindilyakwa speakers accept that these clauses are grammatical and well-formed (with an iterative reading), but still generally disfavour these adverbials in such circumstances, preferring other temporal adverbials that can express both temporal duration and temporal deictic readings (e.g., adhənuba 'in a short time (before/after), soon'; adhəna[k]ba 'first, already'; ar[a]ngkadharrba 'in a short time (before/after), for a short time (before/after), soon'), as shown by speakers' intuitions about these adverbials in such contexts in examples (28) and (29).

28

'Adhuwaya doesn't suit in coughing' (JL, JRB1-083-01, 00:05:14.555-00:06:28.365)

29.

'The language doesn't seem to be connected to each other when you mention adhuwaya' [talking about 'coughing']

(JL, JRB1-083-01, 00:08:30.365-00:08:40.545)

Atomic verbal complexes that are unable to coerce an iterative reading cannot occur in any semantically well-formed manner with the measure adverbials adhuwaya and amiyerra. This is demonstrated in examples (30) and (31).

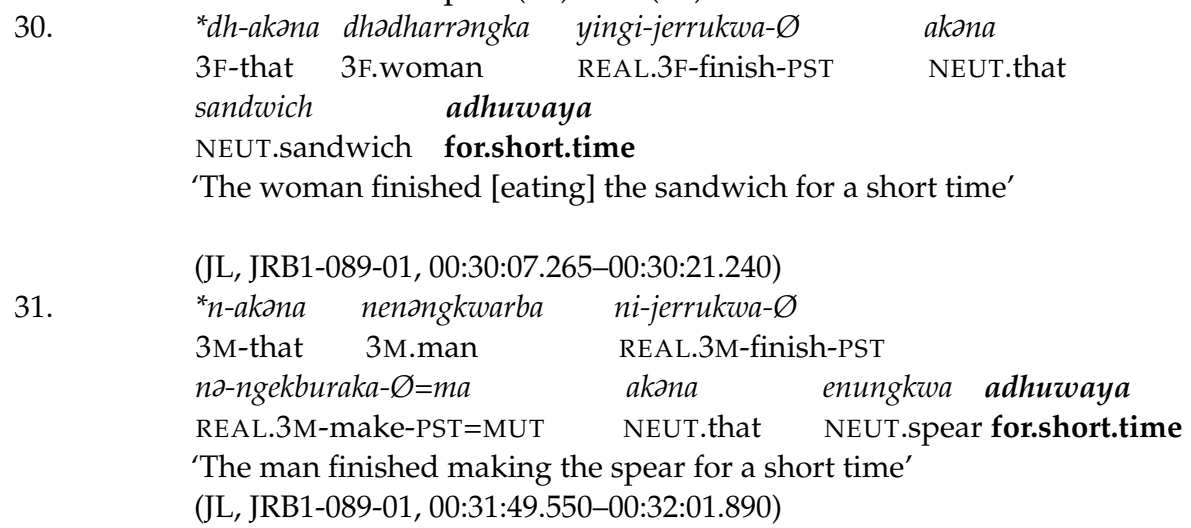




\subsubsection{Implied Durational Adverbials}

In addition to measure adverbials (i.e., direct durational adverbs), adverbials that imply (rather than make explicit) temporal duration (such as the adverbs 'slowly' and 'quickly' in English) can be used as diagnostics for different Aktionsart properties in some languages (Smith 1996, p. 238).

In Anindilyakwa, the indirect durational adverbials waranja 'quickly, soon' and ambaka=lhangwa 'slowly, carefully' are compatible with all dynamic situation types, however with non-atomic ones (as in example (32)), the adverbial modifies the inner stage(s) of the situation, while for atomic events, the adverbial modifies an interval of time preliminary to the event (the preparatory stage(s)), rather than referring to any core inner stage of the situation (as in (33)). The interpretation of such implied durational adverbials can therefore be used as a diagnostic criterion relating to atomicity.

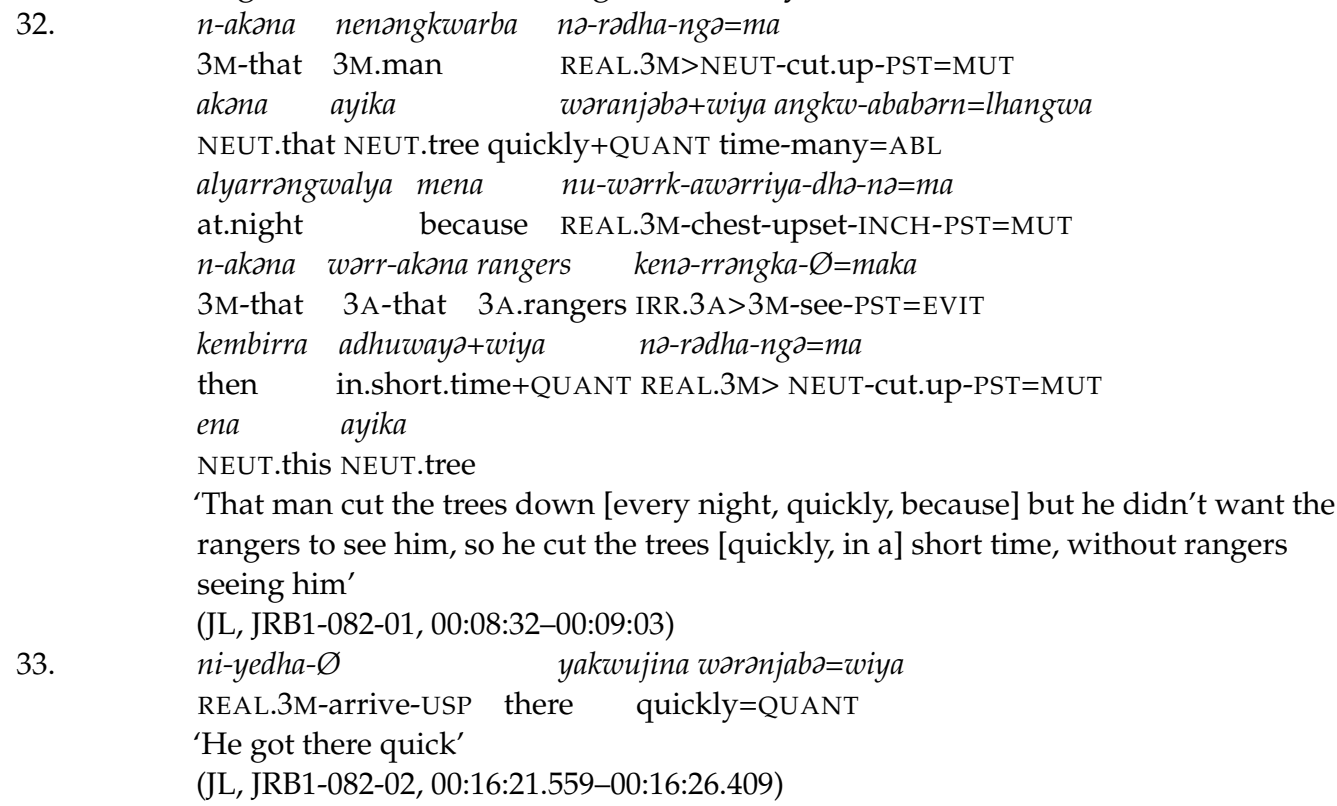

\subsubsection{Interaction with Inflectional $\mathrm{T} / \mathrm{A}$ Marking}

As discussed in Section 4.1, the interaction of Aktionsart with the inflectional TAM system can be used as a diagnostic for the features of both dynamism and atomicity in Anindilyakwa. While non-atomic situations inflected with the REALIS prefix paradigm and the bare stem paradigm (i.e., REALIS-V-USP inflectional marking) are compatible with a present temporal reference point, atomic events that take REALIS-V-USP inflectional marking are compatible only with past temporal expression, as in example (34). Table 3 provides a summary of the effects of Aktionsart on the aspectuo-temporal properties of verbs inflected with REALIS-V-USP marking.

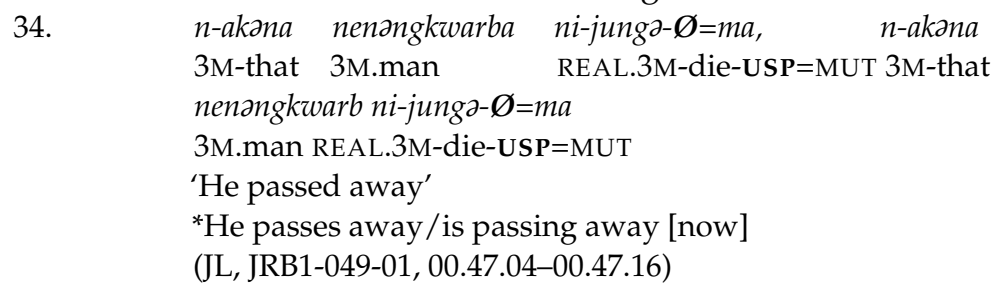

\subsection{Summary}

The key lexical and morpho-syntactic variables that can be used to identify distinctions regarding the inherent temporal properties of different situations in Anindilyakwa, as discussed in Sections 4.1-4.3, are summarised in Table 4. 
Table 4. Aktionsart properties in Anindilyakwa and variables with which to identify them.

\begin{tabular}{|c|c|c|c|c|}
\hline & Stative & $\begin{array}{c}\text { Non-Atomic, } \\
\text { Durative, Atelic }\end{array}$ & Non-Atomic, Telic & Atomic, Telic \\
\hline $\begin{array}{l}\text { Possible with } \\
\text { imperatives? }\end{array}$ & $x$ & $\checkmark$ & $\checkmark$ & $\checkmark$ \\
\hline e.g., & $\begin{array}{c}\text { *Ø-mareya-na } \\
\text { DEON.2-be.hungry- } \\
\text { NPST } \\
\text { 'Be hungry!' }\end{array}$ & $\begin{array}{c}\text { yi-rrangka-Ø } \\
\text { ngayuwə=wa } \\
\text { DEON.2>1-look.at- } \\
\text { USP 1.PRO=ALL } \\
\text { 'Look at me!' }\end{array}$ & $\begin{array}{c}\text { Ø-lhawurradho-na } \\
\text { DEON.2-return-NPST } \\
\text { 'Come back!' }\end{array}$ & $\begin{array}{c}\varnothing \text {-yedhe-na } \\
\text { waranjabə=wiya } \\
\text { DEON.2-arrive-NPST } \\
\text { quickly=QUANT } \\
\text { 'Arrive quickly!' }\end{array}$ \\
\hline $\begin{array}{l}\text { Reduplication (as an } \\
\text { aspect modifier) } \\
\text { expresses only } \\
\text { pluractional reading? }\end{array}$ & $x$ & $x$ & $\checkmark$ & $\mathrm{n} / \mathrm{a}^{11}$ \\
\hline e.g., & $\begin{array}{c}\text { nə-morey-mareya- } \\
\text { nə=ma } \\
\text { REAL.3M-REDUP- } \\
\text { be.hungry-PST=MUT } \\
\text { 'He continued to be } \\
\text { hungry' }\end{array}$ & $\begin{array}{c}n \gtrsim-r r a n g k a-r r a n g k a- \\
n \gtrsim=m a \\
\text { REAL.3M>NEUT- } \\
\text { REDUP-look- } \\
\text { PST = MUT } \\
\text { 'He kept on looking } \\
\text { at it' /'He looked and } \\
\text { looked at it' }\end{array}$ & $\begin{array}{c}\text { na-lhawu- } \\
\text { lhawurradha- } \varnothing \\
\text { REAL.3M-REDUP- } \\
\text { return-USP } \\
\text { 'He kept going back } \\
\text { [i.e., repeatedly } \\
\text { going and returning]' }\end{array}$ & \\
\hline $\begin{array}{l}\text { Reduplicated stem in } \\
\text { positive polarity } \\
\text { context possible with } \\
\text { bare stem inflectional } \\
\text { paradigm } \\
\text { (phonologically } \varnothing \\
\text { TAM slot)? }\end{array}$ & $x$ & $x$ & $\checkmark$ & $\mathrm{n} / \mathrm{a}$ \\
\hline e.g., & $\begin{array}{c}\text { *no-marey-moreya- } \varnothing \\
\text { REAL.3M-REDUP- } \\
\text { be.hungry-USP } \\
\text { 'He keeps on being } \\
\text { hungry' }\end{array}$ & $\begin{array}{l}\text { *na-rrangka-rrangka- } \varnothing \\
\text { REAL.3M>NEUT- } \\
\text { REDUP-look-USP } \\
\text { 'He keeps on looking } \\
\text { at it' /'He looks and } \\
\text { looks at it' }\end{array}$ & $\begin{array}{c}\text { no-lhawu- } \\
\text { lhawurradha- } \varnothing \\
\text { REAL.3M-REDUP- } \\
\text { return-USP } \\
\text { 'He kept going back } \\
\text { [i.e., repeatedly } \\
\text { going and returning]' }\end{array}$ & \\
\hline $\begin{array}{l}\text { Possible with } \\
\text { measure adverbials } \\
\text { (adhuwaya 'for short } \\
\text { time' and amiyerra } \\
\text { 'for long time')? }\end{array}$ & $\checkmark$ & $\checkmark$ & $\checkmark$ & $x$ \\
\hline e.g., & $\begin{array}{c}\text { nə-mareya-nə=ma } \\
\text { adhuwaya } \\
\text { REAL.3M-be.hungry- } \\
\text { PST=MUT } \\
\text { for.short.time } \\
\text { 'He was hungry for a } \\
\text { little while' }\end{array}$ & $\begin{array}{c}\text { nə-rrangka-nə=ma } \\
\text { adhuwaya } \\
\text { REAL.3M>NEUT- } \\
\text { look-PST =MUT } \\
\text { for.short.time } \\
\text { 'He looked at it for a } \\
\text { short time' }\end{array}$ & $\begin{array}{c}\text { nə-lhawurradho- } \\
\text { nə=ma adhuwaya } \\
\text { REAL.3M-return- } \\
\text { PST=MUT } \\
\text { for.short.time } \\
\text { 'He went back for a } \\
\text { short time [i.e., the } \\
\text { duration of the } \\
\text { returning event was } \\
\text { short]' }\end{array}$ & $\begin{array}{c}\text { *ni-yedha-ngə=ma } \\
\text { yakwujina adhuwaya } \\
\text { REAL.3M-arrive- } \\
\text { PST=MUT there } \\
\text { for.short.time } \\
\text { 'He arrived there for } \\
\text { a short time' }\end{array}$ \\
\hline
\end{tabular}


Table 4. Cont.

\begin{tabular}{|c|c|c|c|c|}
\hline & Stative & $\begin{array}{c}\text { Non-Atomic, Durative, } \\
\text { Atelic }\end{array}$ & Non-Atomic, Telic & Atomic, Telic \\
\hline $\begin{array}{l}\text { waranja 'quick, quickly' } \\
\text { and ambaka=lhangwa } \\
\text { 'slow, slowly' modify } \\
\text { inner stage of situation } \\
\text { (rather than } \\
\text { preparatory or result } \\
\text { stages)? }\end{array}$ & \multirow[t]{2}{*}{$\mathrm{n} / \mathrm{a}$} & $\checkmark$ & $\checkmark$ & $x$ \\
\hline e.g., & & $\begin{array}{c}\text { nə-rrangka-nə=ma } \\
\text { waranj }=\text { wiya } \\
\text { REAL.3M }>\text { NEUT-look- } \\
\text { PST=MUT } \\
\text { quickly=QUANT } \\
\text { 'He quickly looked at it' }\end{array}$ & $\begin{array}{c}\text { nə-lhawurradhə- nə=ma } \\
\text { waranjə=wiya } \\
\text { REAL.3M-REDUP- } \\
\text { return- PST=MUT } \\
\text { quickly=QUANT } \\
\text { 'He went back quickly } \\
\text { [i.e., the duration of the } \\
\text { returning event was } \\
\text { quick]' }\end{array}$ & $\begin{array}{c}\text { ni-yedha-Ø yakwujina } \\
\text { waranjabə=wiya } \\
\text { REAL.3M-arrive-USP } \\
\text { there quickly=QUANT } \\
\text { 'He arrived there } \\
\text { quick' /'He got there } \\
\text { quick' }\end{array}$ \\
\hline $\begin{array}{c}\text { Present temporal } \\
\text { interpretation possible } \\
\text { with bare stem } \\
\text { inflectional paradigm } \\
\text { (phonologically Ø TAM } \\
\text { slot)? }\end{array}$ & $\checkmark$ & $\checkmark$ & $\checkmark$ & $x$ \\
\hline e.g., & $\begin{array}{c}\text { na-mareya- } \varnothing \\
\text { anhangu=wa } \\
\text { REAL.3M-be.hungry- } \\
\text { USP NEUT.food=ALL } \\
\text { 'He's hungry for food' }\end{array}$ & $\begin{array}{c}n \partial-r r a n g k a-\varnothing \\
\text { REAL.3M>NEUT-look- } \\
\text { USP } \\
\text { 'He looks at it' }\end{array}$ & $\begin{array}{c}\text { na-lhawurradha- } \varnothing \\
\text { REAL.3M-return-USP } \\
\text { 'He goes back' }\end{array}$ & $\begin{array}{c}\text { ni-yedha-Ø yakwujina } \\
\text { REAL.3M-arrive-USP } \\
\text { there } \\
{ }^{*} \text { He arrives there' }\end{array}$ \\
\hline $\begin{array}{c}\text { Past temporal } \\
\text { interpretation possible } \\
\text { with bare stem } \\
\text { inflectional paradigm } \\
\text { (phonologically Ø TAM } \\
\text { slot)? }\end{array}$ & $x$ & $\checkmark$ & $\checkmark$ & $\checkmark$ \\
\hline e.g., & $\begin{array}{c}\text { nə-məreya-Ø } \\
\text { anhəngu=wa } \\
\text { REAL.3M-be.hungry- } \\
\text { USP NEUT.food=ALL } \\
\text { *`He was hungry for } \\
\text { food' }\end{array}$ & $\begin{array}{c}\text { na-rrangka- } \varnothing \\
\text { REAL.3M>NEUT-look- } \\
\text { USP } \\
\text { 'He looked at it' }\end{array}$ & $\begin{array}{c}\text { no-lhawurradha- } \varnothing \\
\text { REAL.3M-return-USP } \\
\text { 'He went back' }\end{array}$ & $\begin{array}{c}\text { ni-yedha-Ø yakwujina } \\
\text { REAL.3M-arrive-USP } \\
\text { there } \\
\text { 'He arrived there' }\end{array}$ \\
\hline
\end{tabular}

\section{Conclusions}

In this article we have seen that intrinsic temporal properties of the verbal complex are integral to the system of aspectual expression in Anindilyakwa, particularly given the underspecified nature of the inflectional aspectuo-temporal system.

Salient Aktionsart properties were identified in Anindilyakwa by examining the grammatically permissible (and impermissible) distribution and co-occurrence of various temporal adverbials (primarily measure adverbials and indirect duration adverbials), as well as through examining morpho-syntactic properties of reduplication patterns and inflectional TAM marking. Through this examination, it was observed that some of the most salient variables that can be used to identify distinctions with respect to the inherent temporal properties of different Anindilyakwa verbal complexes relate to the properties of dynamism and atomicity. Telicity was observed as less salient than other parameters in distinguishing between different kinds of situations in Anindilyakwa. 
This article, through its language-specific means of identifying and classifying Aktionsart properties, offers new perspectives with which to consider cross-linguistic aspectuotemporal research, in addition to providing a more detailed and nuanced understanding of aspectuo-temporal semantics in Anindilyakwa.

Funding: This research was funded by the ARC Centre of Excellence for the Dynamics of Language (Project ID: CE140100041), an Australian Government Research Training Program Scholarship, the School of Literature, Languages and Linguistics at the Australian National University, and the Laboratoire de Linguistique Formelle (LLF) UMR7110 at Université de Paris (formerly Université Paris Diderot).

Institutional Review Board Statement: Data collection for this study was approved by the $\mathrm{Hu}-$ man Research Ethics Committee at the Australian National University (Protocol 2015/143) and the Anindilyakwa Services Aboriginal Corporation.

Informed Consent Statement: Informed consent was obtained from all subjects involved in the study.

Data Availability Statement: Recordings cited here are archived with the Pacific and Regional Archive for Digital Sources in Endangered Cultures (PARADISEC) (https:/ / catalog.paradisec.org. $\mathrm{au} /$ collections/JRB1 accessed on 24 September 2021) and the Australian Institute of Aboriginal and Torres Strait Islander Studies (Groote_E01 Collection, Waddy_J01 Collection, Waddy_J02 Collection).

Acknowledgments: I am indebted to the Warnumamalya people of the Groote Eylandt archipelago, who have generously and patiently taught me about their Anindilyakwa language. In particular I thank Judy Lalara, Sylvia Tkac and Carol Wurramara. I thank Patrick Caudal and Jane Simpson, whose mentorship and supervision was crucial for the larger project on which this study is based. I thank two anonymous reviewers for their valuable comments. Any errors or oversights are, of course, my own.

Conflicts of Interest: The author declares no conflict of interest. The funding bodies had no role in the design of the study; in the collection, analyses, or interpretation of data; in the writing of the manuscript; or in the decision to publish the results.

\begin{tabular}{|c|c|c|c|}
\hline 1 & first person (exclusive) & M & masculine gender \\
\hline 2 & second person & & marker of symmetrical information access \\
\hline 3 & third person & MUT & from speaker perspective \\
\hline A & augmented & NEG & negative \\
\hline $\mathrm{ABL}$ & ablative & NEUT & neuter nominal class \\
\hline ALL & allative & NPST & non-past \\
\hline COLL & collective noun class & PERL & perlative \\
\hline COMPL.ACT & completed action & POSS & possessive \\
\hline DEON & deontic & PRO & pronoun \\
\hline DIM & diminutive & PST & past \\
\hline EVIT & evitative & PURP & purposive \\
\hline $\mathrm{F}$ & feminine gender & QUANT & quantitative \\
\hline FACT & factitive & REAL & realis \\
\hline $\mathrm{INCH}$ & inchoative & REDUP & reduplication \\
\hline IRR & irrealis & TRM & terminative \\
\hline KIN & possessed kin & USP & underspecified, phonologically null TAM \\
\hline
\end{tabular}

\section{Notes}

1 Various terms have been employed in the literature to refer to this domain, including 'Aktionsart', 'action', 'actionality', 'aspectual character', 'aspectual class', 'situation type' and 'event structure aspect' (amongst others). Throughout this article I use the term 'Aktionsart'.

2 Although for detailed studies considering various other topics within the temporal/aspectual domain in a number of Australian languages, see the special issue of the Australian Journal of Linguistics 32(1) (2012), along with Bednall (2020, Forthcoming), Collins (2015), Phillips (2021) and Ritz and Schultze-Berndt (2015). 
3 The 2016 Australian Bureau of Statistics Census recorded 1478 people reporting to speak Anindilyakwa, including 377 children under 14 years old, however this is likely an underestimate (cited in Department of Infrastructure, Transport, Regional Development and Communications et al. 2020, pp. 48-49).

4 This data was collected predominantly with three language consultants (all female, born in the 1950s-70s, and from the community of Angurugu). This data is available at https:// catalog.paradisec.org.au/collections/JRB1 (accessed on 9 April 2021).

5 Staged video stimuli were used as the primary semi-elicited data collection method. The video stimuli used came from the Event Description Elicitation Database (EDED) (Caudal et al. 2016).

6 I use the following conventions: * marks unacceptability; \# indicates that the sentence is acceptable but cannot be given the interpretation in question.

$7 \quad$ Rows shaded in grey indicates that this combination of prenominal prefix + TAM suffix is not possible.

8 Most temporal adverbials associated with duration in Anindilyakwa are multifunctional, being able to express readings associated with both duration as well as temporal deixis, however adhuwaya 'for short [duration of] time' and amiyerra 'for long [duration of] time' are not, expressing only a durative meaning.

9 More generally in Anindilyakwa, for telic events involving a verbal predicate inflected for REALIS-V-PAST or IRREALIS-V-PAST marking, both culminating and non-culminating readings are possible-there is an implicature of culmination, however this can be cancelled (generally through a following clause that specifies the non-culmination). On the other hand, telic events involving verbal predicates inflected for REALIS-V-USP or IRREALIS-V-USP entail that culmination occurred (i.e., a non-culminating reading is disallowed). Compare examples (a) and (b), and see Bednall (2020, chp. 4) for further details.

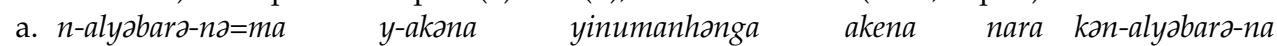

REAL.3M-eat-PST=MUT MASC-that MASC.wild.apple but NEG IRR.3M>MASC-eat-PST

'He ate the wild apple, but he didn't eat it' (i.e., 'he ate/began to eat the wild apple, but didn't finish it')

(JL, PL, CW, fieldnotes, 19 July 2018).

b. *n-alyabaru- $\varnothing=m a \quad y$-akana yinumanhanga akena nara kan-alyabara-na

REAL.3M-eat-USP=MUT MASC-that MASC.wild.apple but NEG IRR.3M $>$ MASC-eat-PST

'He ate the wild apple [i.e., began to eat, started eating], but he didn't eat it'

(JL, PL, CW, fieldnotes, 19 July 2018).

10 In some of these examples amiyerra occurs with the DIMINUTIVE prefix -warnk-, which indicates the time span referred to is smaller than amiyerra (often translated as 'a little bit long time'; i.e., 'a fairly long time').

11 No examples of reduplicated verbal roots of atomic events have been identified in the existing corpora.

\section{References}

Bache, Carl, Hans Basbøll, and Carl-Erik Lindberg, eds. 1994. Tense, Aspect and Action: Empirical and Theoretical Contributions to Language Typology. Berlin: Mouton de Gruyter.

Bednall, James. 2020. Temporal, Aspectual and Modal Expression in Anindilyakwa, the Language of the Groote Eylandt Archipelago, Australia. Ph.D. thesis, 2020, Australian National University, Canberra, Australia, Université de Paris, Paris, France. [CrossRef]

Bednall, James. Forthcoming. Tense and aspect. In The Oxford Guide to Australian Languages. Edited by Claire Bowern. Oxford: Oxford University Press.

Bible Society in Australia. 1992. Neningikarrawara-Langwa Ayakwa [=Anindilyakwa Bible]. Canberra: Bible Society in Australia.

Carlson, Gregory. 1977. A unified analysis of the English bare plural. Linguistics and Philosophy 1: 413-56. [CrossRef]

Carlson, Gregory. 1980. Reference to kinds of English. New York: Garland Publishing Company.

Caudal, Patrick. 1999. Computational lexical semantics incrementality and the so-called punctuality of events. In Proceedings of the 37th annual meeting of the Association for Computational Linguistics on Computational Linguistics. Stroudsburg: Association for Computational Linguistics, pp. 497-504. [CrossRef]

Caudal, Patrick. 2005. Degree Scales and Aspect. In Cross-Linguistic Views on Tense, Aspect and Modality. Edited by Bart Hollebrandse, Angeliek van Hout and Co Vet. Amsterdam and New York: Rodopi, pp. 103-18.

Caudal, Patrick. 2006. The Aspectual Contribution of Tenses and the Semantics/Pragmatics Interface. Paper presented at UT Discourse Workshop, Austin, TX, USA, March 3-5; Available online: https:/ / citeseerx.ist.psu.edu/viewdoc/download?doi=10.1.1.584.905 $1 \&$ rep $=$ rep $1 \&$ type $=$ pdf (accessed on 24 September 2021).

Caudal, Patrick. 2012. Pragmatics. In The Oxford Handbook of Tense and Aspect. Edited by Robert Binnick. Oxford: Oxford University Press, pp. 269-305.

Caudal, Patrick, and Laurent Roussarie. 2000. Event structure vs. stage structure and abstract aspectual relations. In Proceedings of the 26th Annual Meeting of the Berkeley Linguistics Society: General Session and Parasession on Aspect. Edited by Andrew K. Simpson. Berkeley: Berkeley Linguistics Society, pp. 361-72. Available online: https://halshs.archives-ouvertes.fr/halshs-01450454 (accessed on 24 September 2021).

Caudal, Patrick, Robert Mailhammer, and James Bednall. 2016. The Event Description Elicitation Database (EDED). Paris: U. Paris-Diderot, Sydney: U. Western Sydney. 
Collins, Brighde. 2015. Aspectual Expression in Ngandi: Past and Present. Master's thesis, University of Melbourne, Melbourne, Australia. Available online: http:/ / hdl.handle.net/11343/56545 (accessed on 24 September 2021).

Comrie, Bernard. 1976. Aspect. Cambridge: Cambridge University Press.

Department of Infrastructure, Transport, Regional Development and Communications, Jacqueline Battin, Jason Lee, Douglas Marmion, Rhonda Smith, Tandee Wang, Yonatan Dinku, Janet Hunt, Francis Markham, Denise Angelo, and et al. 2020. National Indigenous Languages Report; Canberra: Australian Government Department of Infrastructure, Transport, Regional Development and Communications, formerly the Department of Communications and the Arts. Available online: https://www.arts.gov.au/whatwe-do/indigenous-arts-and-languages/national-indigenous-languages-report (accessed on 24 September 2021).

Dowty, David R. 1972. Studies in the Logic of Verb Aspect and Time Reference in English. Ph.D. thesis, Univsity of Texas, Austin, TX, USA.

Dowty, David R. 1979. Word Meaning and Montague Grammar. Dordrecht: Reidel.

Dowty, David R. 1991. Thematic proto-roles and argument selection. Languages 67: 547-619. [CrossRef]

Filip, Hana. 2012. Lexical aspect. In The Oxford Handbook of Tense and Aspect. Edited by Robert Binnick. Oxford: Oxford University Press, pp. 721-51.

Harvey, Mark. 2008. Non-Pama-Nyungan Languages: Mapping Database and Maps [Online]. ASEDA. Available online: http: //www1.aiatsis.gov.au/aseda/802_Harvey/MH_top_end.png (accessed on 15 December 2015).

Kearns, Kate. 2000. Semantics. Basingstoke: Macmillan.

Kennedy, Christopher, and Louise McNally. 1999. Degree modification and the scalar structure of gradable adjectives. In Description des Adjectifs pour les Traitements Informatiques (Proceedings of TALN 1999). Edited by Pierrette Bouillon and Evelyne Viegas. Cargèse: Association pour le Traitement Automatique des Langues, pp. 98-107.

Kennedy, Christopher, and Louis McNally. 2005. The Syntax and Semantics of Multiple Degree Modification in English. In Proceedings of the 12th International Conference on Head-Driven Phrase Structure Grammar. Edited by Stefan Müller. Stanford: CA CSLI Publications, pp. 178-91. Available online: https://semantics.uchicago.edu/kennedy/docs/kennedy-mcnally05.pdf (accessed on 24 September 2021).

Leeding, Velma. 1989. Anindilyakwa Phonology and Morphology. Ph.D. thesis, University of Sydney. Available online: http: / / hdl.handle.net/2123/1558 (accessed on 24 September 2021).

Moens, Marc. 1987. Tense, Aspect, and Temporal Reference. Ph.D. thesis, University of Edinburgh, Edinburgh, UK. Available online: http:/ / hdl.handle.net/1842/5369 (accessed on 24 September 2021).

Moens, Marc, and Mark Steedman. 1988. Temporal ontology and temporal reference. Computational Linguistics 14: 15-28.

Mucha, Anne. 2015. Temporal Interpretation and Cross-Linguistic Variation. Ph.D. thesis, University of Potsdam, Potsdam, Germany. Available online: https://publishup.uni-potsdam.de/opus4-ubp/frontdoor/deliver/index/docld/8593/file/mucha_diss.pdf (accessed on 24 September 2021).

Phillips, Joshua. 2021. At the Intersection of Temporal and Modal Interpretation: Essays on Irreality. Ph.D. thesis, Yale University, New Haven, CT, USA.

Ritz, Marie-Eve, and Eva Schultze-Berndt. 2015. The semantics and pragmatics of marking temporal progression in an Australian language. Lingua 166: 1-21. [CrossRef]

Sasse, Hans-Jürgen. 2002. Recent activity in the theory of aspect: Accomplishments, achievements, or just non-progressive state? Linguistic Typology 6: 199-271. [CrossRef]

Smith, Carlota. 1996. Aspectual categories in Navajo. International Journal of American Linguistics 62: 227-63. [CrossRef]

Smith, Carlota. 1997. The Parameter of Aspect, 2nd ed. Dordrecht: Kluwer.

Tatevosov, Sergej. 2002. The parameter of actionality. Linguistic Typology 6: 317-401. [CrossRef]

Tonhauser, Judith. 2015. Cross-linguistic temporal reference. Annual Review of Linguistics 1: 129-54. [CrossRef]

Vendler, Zeno. 1957. Verbs and Times. The Philosophical Review 66: 143-60. [CrossRef]

Verkuyl, Henk J. 1972. On the Compositional Nature of the Aspects. Dordrecht: Reidel. [CrossRef] 